\title{
Durabilidad de pastas de cemento API clase B expuestas a disoluciones acuosas de iones cloruro, sulfato y magnesio
}

\section{Durability of API class B cement pastes exposed to aqueous solutions containing chloride, sulphate and magnesium ions}

\author{
J. J. Martín ${ }^{(*)}$, G. Márquez(**), F. J. Alejandre(*) y M. E. Hernández(***)
}

Recepción/Received: 27-VII-06

Aceptación/Accepted: 10-X-07

Publicado online/Online publishing: 1-XII-08

\section{RESUMEN}

Este trabajo se basa en el estudio de la durabilidad de un cemento API clase $B$, utilizado en pozos petrolíferos someros, frente a la agresividad de las aguas de formación a las que puede estar expuesto. Su eficacia frente a la exposición a los iones más importantes $-\mathrm{SO}_{4}=, \mathrm{Mg}^{+2}$ y $\mathrm{Cl}^{-}-$se relaciona con su capacidad de asimilar la acción agresiva de cada agente perjudicial, así como de las reacciones químicas que sufra por la reactividad de alguno de sus compuestos. La metodología aplicada supone la preparación de probetas de este cemento y su inmersión en disoluciones neutras, conteniendo los referidos iones a distintas concentraciones, para evaluar el desarrollo de las reacciones existentes en su seno. A tal fin se realizaron análisis de las disoluciones y estudios de DRX durante más de un año para conocer su evolución mineralógica. El objetivo del trabajo ha sido determinar los efectos resultantes de los ataques conjuntos de los citados iones al referido cemento; así como la observación de las variaciones de las concentraciones de calcio en diferentes disoluciones acuosas de $\mathrm{Na}_{2} \mathrm{SO}_{4}, \mathrm{MgCl}_{2}$ y $\mathrm{NaCl}$ en contacto con pastas de cemento API clase B.

Palabras clave: durabilidad, cemento API clase B, aguas de formación, cloruro, sulfato e ión magnesio.

\section{SUMMARY}

This paper discusses a durability study conducted on API class B cement, the type used in shallow oil wells, when exposed to aggressive formation water. Its resistance to the major ions, namely $-\mathrm{SO}_{4}=, \mathrm{Mg}^{+2}$ and $\mathrm{Cl}^{-}$, is related both to its capacity to assimilate the aggressive action of each harmful agent and to the changes in the chemical reactivity of some of its components. The methodology used consisted in preparing and immersing cement specimens in neutral solutions containing variable concentrations of these ions to monitor the chemical reactions taking place. These solutions were analyzed and XRD studies were conducted for over a year to identify mineralogical variations. The purposes of the study were to determine the effects of joint ionic attack on this kind of cement and to monitor the variations in the calcium concentration in the aqueous solutions of $\mathrm{Na}_{2} \mathrm{SO}_{4}, \mathrm{MgCl}_{2}$ and $\mathrm{NaCl}$ in contact with API class $B$ cement pastes.

Keywords: durability, API class B cement, formation water, chloride, sulphate, magnesium ion.

\footnotetext{
(*) Universidad de Sevilla (Sevilla, España).

(**) Universidad de Huelva (Huelva, España).

(***) Universidad Central de Venezuela (Caracas, Venezuela).
} 


\section{INTRODUCCIÓN}

La durabilidad de un cemento es su capacidad de resistencia a lo largo del tiempo frente a una variada gama de acciones, químicas o no, de carácter agresivo (1). En este caso, el material se ve sometido a la acción de agentes agresivos presentes en aguas de yacimientos petrolíferos que superan los 40000 ppm de sustancias disueltas, llegando a veces hasta 300000 ppm (2). Ello puede traducirse en una sinergia de acciones distintas que multiplicará el efecto dañino sobre el cemento. No existe un ensayo específico para evaluar la durabilidad, pero sí métodos para estimar una serie de características del cemento que permitan garantizar en el mismo dicha propiedad (3).

Durante la perforación, el reacondicionamiento y abandono de pozos someros se utiliza el cemento estudiado para aislar estratos acuíferos o taponar influjos indeseables de aguas de formación. Este material, muy similar a los cementos CEM II o ASTM tipo II, sufre un deterioro prematuro bajo la acción de diferentes agentes agresivos (4). La complejidad de los efectos ambientales sobre tales estructuras y su correspondiente respuesta obliga a mejorar las características de los materiales y los procedimientos de ejecución de las operaciones de cementación propias de pozos petrolíferos (5).

En la práctica, los principales procesos químicos que pueden conducir a un deterioro del cemento son la reacción de sales magnésicas y cloruros disueltas en aguas de formación con el cemento endurecido (6), el ataque de sulfatos a las fases alumino-férricas de dicho material (7) o la carbonatación de compuestos cálcicos (8).

En particular, se utilizó cemento API clase B en los pozos perforados en los campos petroleros de Socororo, Cachicamo y Caricari, ubicados geológicamente en la parte suroeste de la Cuenca Oriental de Venezuela y, geográficamente, en las cercanías de la población de Pariaguán. Un total de 93 pozos fueron perforados en los tres campos, de los cuales 58 resultaron productores. Actualmente, sólo existen dos pozos productores de petróleo activos, SOC-3 y ES-446, ambos ubicados en el campo de Socororo. Asimismo, la columna sedimentaria penetrada por dichos pozos está constituida, de menor a mayor profundidad, por las siguientes Formaciones: Mesa, Las Piedras, Freites, Oficina, Merecure, Canoa y Tigre. Las Formaciones Merecure y Oficina son las únicas de interés como productoras comerciales de hidrocarburos.

La Formación Mesa se caracteriza, desde un punto de vista litológico, por la presencia de arenas de grano grueso y gravas, así como conglomerados ferruginosos; la Formación las Piedras por areniscas micáceas, friables y de grano fino, interlaminadas con lutitas, arcilitas siderí-

\section{INTRODUCTION}

Cement durability depends on its resistance to a wide range of aggressive actions, chemical or otherwise, over time (1). The type studied here is exposed to the agents dissolved in the water in oil deposits (from 40000 to 300000 ppm) (2). The combined presence of different substances may translate into synergetic action that intensifies the harmful effects on the cement. While no specific test has been developed to evaluate durability, a number of methods can be used to estimate the characteristics that guarantee long-lasting cement (3).

The cement studied here is used in shallow oil wells, to isolate aquifer strata or seal the wells off from undesired formation water during drilling, reconditioning and abandonment. This material, which is very similar to Spanish CEM II or ASTM type II cement, undergoes premature decay when exposed to aggressive agents (4). The complexity of the environmental effects on such structures and their response necessitate improvements in both material characteristics and the placement procedures used in oil wells (5).

In practice, the main chemical processes that may lead to cement deterioration include the reaction between the magnesium and chloride salts in formation water and the hardened cement (6), sulphate attack on aluminoferric cement components (7) and carbonation of calcium compounds (8).

Specifically, API class B cement was used in the wells drilled in the Socorro, Cachicamo and Caricari oilfields, located in the southwestern quadrant of Venezuela's Eastern Basin, near the town of Pariaguán. A total of 93 wells were drilled in the three fields, 58 of which were found to be productive. At present, only two of the productive wells are active, SOC-3 and ES-446, both located on the Socorro oilfield. The sedimentary column penetrated by the wells comprises the following formations, listed in descending order: Mesa, Las Piedras, Freites, Oficina, Merecure, Canoa and Tigre. The only two formations of commercial interest for hydrocarbon production are Merecure and Oficina.

Lithologically speaking, the Mesa formation is characterized by the presence of coarse grain sand and gravel, along with ferruginous conglomerate; las Piedras by micaceous, crumbly, fine grain sandstone with interlaid lutite, sideritic argillite and lignite; Freites is essentially 
ticas y lignitos; en contraste con la Formación Freites, esencialmente lutítica. Asimismo, la Formación Oficina consiste en una interestratificación de arenas, limolitas y lutitas. La Formación Canoa está constituida por areniscas arcósicas, limolitas y arcilitas; mientras la Formación Tigre se compone por areniscas, limolitas, lutitas y capas de calizas dolomíticas.

La profundidad de ambos pozos activos es, respectivamente, de 3900 y $4100 \mathrm{ft}$; las temperaturas estática y circulante consideradas para ambos pozos son 151 of y 104 oF, respectivamente; el gradiente de fractura viene a ser de $0,715 \mathrm{lpg} / 100$ pies y el gradiente de temperatura de 1.73 oF/100 pies. El lodo de perforación fue bentonítico o polimérico, ambos de 8,9 lpg. Además, la empresa CORPOMENE C.A. estima la presión actual por encima de 1000 psi, comparada con una presión inicial promedio de 1700 psi. El fluido de control usado en los referidos pozos petroleros fue de base acuosa, bajo en coloide y con lignosulfonato. Asimismo, el agua empleada en las lechadas de cemento preparadas es similar a la usada en las operaciones, la cual procede de pozos y lagunas de agua dulce, libres de fertilizantes, productos agrícolas y ácido húmico, sustancias que retardan el espesamiento del cemento (9). Además, las medidas de $\mathrm{pH}$, cloruros y sulfatos arrojaron unos valores aceptables.

Entre los iones agresivos presentes en las aguas de formación que pueden estar en contacto con el cemento API clase B destacan los denominados iones fundamentales (sulfato, cloruro o magnesio) y gases como el dióxido de carbono. De los componentes del cemento, particularmente susceptibles a ser atacados son algunas de las fases presentes en el clínker: el aluminato tricálcico $\left(C_{3} A\right)$ y el ferritoaluminato tetracálcico $\left(C_{4} A F\right)$ pueden reaccionar con el ión sulfato, formando ettringita expansiva $\left(A F_{t}\right)$ que causa la fisuración del material y potencia la acción agresiva del ión cloruro (10) al facilitar la difusión de cloruros a través del cemento API clase $B$, causando la despasivación de aquellos elementos de acero -previamente usados en tareas de perforación y terminación de cualquier pozo de petróleo- embebidos accidentalmente en la pasta; por contra, los silicatos anhidros bicálcico $\left(\mathrm{C}_{2} \mathrm{~S}\right)$ y tricálcico $\left(\mathrm{C}_{3} \mathrm{~S}\right)$ se hidratan originando portlandita $(\mathrm{CH})$ que, a su vez, provoca que el pH del cemento sea superior a 12.5, evitando fenómenos de corrosión (11).

Con la preparación de disoluciones conteniendo estos agentes agresivos que pueden afectar gravemente la durabilidad del cemento, se pretende estudiar el efecto sinérgico que pueden ejercer estos iones entre sí. Más concretamente, para evaluar la acción conjunta de los iones sulfato y cloruro, lo que se ha hecho es variar la concentración de ión sulfato, mientras se han mantenido las mismas proporciones fijas de ión cloruro en diferentes disoluciones agresivas; observándose la influencia del pri- lutitic. The Oficina formation, in turn, consists in interstratified sand, siltstone and lutite. Canoa includes arkosic sandstone, siltstone and argillite, while the Tigre formation comprises sandstone, siltstone, lutite and layered dolomitic limestone.

The two active wells are 3900 and 4100 feet deep, respectively; the static and circulating temperatures are estimated to be 151 of and 104 of, respectively, for both; the fracture gradient is $0.715 \mathrm{ppg} / 100$ feet and the temperature gradient 1.73 of/100 feet. The drilling mud proved to be bentonitic or polymeric and the density in both wells was 8.9 ppg. The current pressure is estimated by CORPOMENE C.A., oil industry consultants, to be upward of 1000 psi, compared to an initial mean pressure of 1700 psi. The control fluid used in the oil wells was a waterbase solution with a low colloid content and some lignosulphonate. The water used in the cement specimens prepared for the study, in turn, was similar to the water used in field operations, drawn from freshwater wells and lagoons and free of fertilizers, farming products and humic acid, all of which retard cement thickening (9). The $\mathrm{pH}$, as well as the chloride and sulphate content, were likewise acceptable.

The chief aggressive agents present in the formation water that may come into contact with API class $B$ cement are the so-called major ions (sulphate, chloride and magnesium) and carbon dioxide gas. Of all the cement components, some of the phases present in the clinker are most susceptible to attack: tricalcium aluminate $\left(C_{3} A\right)$ and tetracalcium aluminoferrite $\left(C_{4} A F\right)$ may react with sulphate ions to form expansive ettringite $\left(A f_{t}\right)$, which prompts cracking and heightens the aggressive action of chloride ions (10) by facilitating their dissemination through the cement. This, in turn, causes de-passivation of any steel elements (used in prior drilling and finishing operations in oil wells) accidentally embedded in the paste. Anhydrous bi- and tricalcium silicates $\left(C_{2} S\right)$, by contrast, hydrate to form portlandite $(\mathrm{CH})$, which raises cement $\mathrm{pH}$ to values of over 12.5 , thereby preventing corrosion (11).

Solutions containing pairs of the aggressive agents that may adversely affect cement durability were prepared to study their possible synergies. More specifically, to evaluate the joint action of sulphate and chloride ions, sulphate ion concentration was varied while the chloride content was kept constant in different aggressive solutions. The effect of the former on the aggressive behaviour of the latter was observed by determining the presence in these solutions of the calcium ions leached from 
mero respecto al comportamiento agresivo del segundo mediante la determinación del ión calcio, procedente de la pasta, presente en dichas disoluciones. La concentración de este último es el parámetro cuyo control periódico posibilita evaluar las transformaciones químicas acontecidas en el seno de dicha pasta. Al igual que en el caso de los iones sulfato y cloruro, diferentes disoluciones conjuntas de los iones magnesio y cloruro permiten evaluar la acción agresiva del primero en presencia de distintas concentraciones del segundo. La preparación de disoluciones de sulfato, magnesio y cloruro es importante a fin de observar el efecto conjunto que puedan ejercer todos ellos combinados entre sí. Finalmente, se realizaron las caracterizaciones mineralógicas de las pastas de cemento a distintas edades mediante DRX.

\section{PARTE EXPERIMENTAL}

La metodología aplicada consiste en la preparación de probetas de cemento API clase B altamente resistente al sulfato, utilizado en pozos a profundidades de hasta 1800 $\mathrm{m}$, y la inmersión de las mismas en disoluciones agresivas de un litro de volumen. Los reactivos de calidad analítica utilizados en el presente trabajo son: agua destilada, cloruro sódico, sulfato sódico y cloruro magnésico. Además, se ha hecho uso de un cemento de composición química característica (Tabla 1) y composición potencial del clínker igual a $15,18 \% \mathrm{C}_{2} \mathrm{~S}, 64,34 \% \mathrm{C}_{3} \mathrm{~S}, 2,88 \% \mathrm{C}_{3} \mathrm{~A}$ y $12,20 \% \mathrm{C}_{4} \mathrm{AF}$; siendo la relación agua/cemento de 0,46 .

La imagen microscópica del clínker en estudio (Figura 1), obtenida con un equipo Zeiss Axiotech, permite observar los cristales de alita idiomórficos, con esquinas bien definidas, así como los cristales de belita redondeados, con orillas lisas. La celita se considera conjuntamente con la masa intersticial del referido clínker, compuesta por fundidos luminosos de color claro y ferríticos de color oscuro. the paste. $\mathrm{Ca}^{2+}$ concentration was also the parameter that was periodically monitored to evaluate the chemical changes taking place in the paste. Analogously, different solutions of magnesium and chloride ions were used to determine the aggressive action of the former at different concentrations of the latter, while sulphate and magnesium solutions were prepared to observe the combined effect of these agents. Finally, XRD techniques were used to characterize cement mineralogy in 28- and 365-day pastes.

\section{EXPERIMENTAL}

Specimens were made with the sulphate-resistant API class B cement used in oil wells with depths of up to 1800 $m$ and immersed in one litre of aggressive solution. All the reagents used in the experiment (distilled water, sodium chloride, sodium sulphate and magnesium chloride) were of analytical quality. The chemical composition of the cement used is given in Table 1 , while the potential clinker composition was: $15.18 \% C_{2} S, 64.34 \% C_{3} S$, $2.88 \% C_{3} A$ and $12.20 \% C_{4} A F$. The water/cement ratio was 0.46 .

The micrograph of the clinker in Figure 1, obtained with a Zeiss Axiotech microscope, shows both idiomorphic alite crystals with well-defined corners and rounded, smooth-edged belite crystals. The diatomite present was considered to form part of the interstitial mass of the clinker, consisting in a blend of light-coloured luminous and dark ferritic materials.

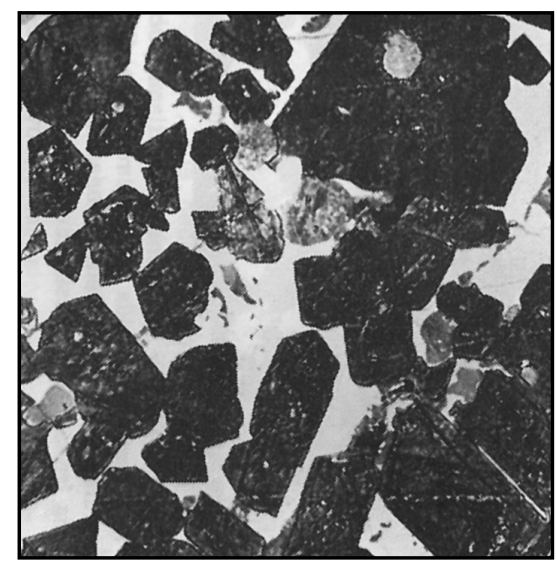

Figura 1. Imagen del clínker con cristales y masa intersticial observados a luz refractada de modo inverso.

Figure 1. Image of clinker showing crystals and fused material observed through inverse mode refracted light. 
Las propiedades físicas del cemento estudiado (Tabla 1) fueron obtenidas utilizando un termostato de inmersión Selecta modelo Digiterm-200, una mezcladora Chadler modelo 3060, una balanza presurizada y un cilindro graduado marca Halliburton, un viscosímetro rotacional Fann modelo 35, un consistómetro atmosférico Chadler modelo 1250 , una cámara de curado Chadler modelo CC1, un consistómetro presurizado Chadler modelo CP8 y una prensa Shimadzu modelo UH20A. Los valores del área superficial específica obtenidos mediante turbidímetro y permeabilímetro fueron medidos, respectivamente, mediante un equipo Wagner marca Tecnotest y un dispositivo Mastrad tipo Blain. La expansión por sulfatos, a su vez, se obtuvo conforme a lo referido en la norma ASTM C 1012, utilizando un molde de expansión Halliburton y un tornillo micrométrico marca VIS.
The physical properties of the cement (Table 1) were determined with the following equipment: Selecta Digiterm-200 immersion thermostat, Chadler 3060 mixer, Halliburton pressure scales and graduated cylinder, Fann 35 rotational viscometer, Chadler 1250 atmospheric pressure consistometer, Chadler CC1 curing chamber, Chadler CP8 pressurized consistometer and Shimadzu UH20A testing machine. The specific surface values were obtained with a Wagner Tecnotest turbidimeter and a Mastrad Blain permeameter. Sulphate-induced expansion, in turn, was found as specified in ASTM standard C 1012, using a Halliburton expansion mould and a VIS micrometric screw.

Tabla 1 / Table 1

Composición química y propiedades físicas del cemento API clase B. Chemical composition and physical properties of API class B cement.

\begin{tabular}{|c|c|c|}
\hline $\begin{array}{l}\text { Parámetro } \\
\text { Parameter }\end{array}$ & $\begin{array}{l}\text { Valor } \\
\text { Value }\end{array}$ & $\begin{array}{c}\text { Requisito API } \\
\text { API Requirement }\end{array}$ \\
\hline Óxido de magnesio / Magnesium oxide & $2.10 \%$ & $<6 \%$ \\
\hline Trióxido de azufre / Suphur trioxide & $1.70 \%$ & $<3 \%$ \\
\hline Pérdida por ignición / Loss on ignition & $1.12 \%$ & $<3 \%$ \\
\hline Residuo insoluble / Insoluble residue & $0.31 \%$ & $<0.75 \%$ \\
\hline Peso específico / Specific gravity & 3.15 & - \\
\hline Consistencia de 15 a $30 \mathrm{~min}$ / Slurry consistency from 15 to $30 \mathrm{~min}$ & $15 \mathrm{BC}$ & $<30 \mathrm{Bc}$ \\
\hline Tiempo bombeable a $100 \mathrm{Bc} /$ Thickening time at $100 \mathrm{BC}$ & $120 \mathrm{~min}$ & $>90 \min$ \\
\hline Resistencia a compresión a $8 \mathrm{~h}$ y $100^{\circ} \mathrm{F} /$ Compressive strength at $8 \mathrm{~h}$ and 100 of & $720 \mathrm{psi}$ & $>200$ psi \\
\hline Resistencia a compresión a $24 \mathrm{~h}$ y 100 of / Compressive strength at $24 \mathrm{~h}$ and $100^{\circ} \mathrm{F}$ & $3200 \mathrm{psi}$ & $>1500 \mathrm{psi}$ \\
\hline Viscosidad plástica a 80 of / Plastic viscosity at 80 oF & $29 \mathrm{cp}$ & - \\
\hline Punto cedente a 80 o F / Yield stress at 80 oF & $14 \mathrm{lbf} / 100 \mathrm{ft}^{2}$ & - \\
\hline Expansión por sulfatos / Sulphate expansion & $0.09 \%$ & $<0.1 \%$ \\
\hline Superficie específica Wagner / Wagner specific surface & 180 & $>160 \mathrm{~m}^{2} / \mathrm{Kg}$ \\
\hline Superficie específica Blaine / Blaine specific surface & 336 & $>280 \mathrm{~m}^{2} / \mathrm{Kg}$ \\
\hline
\end{tabular}

Se realizaron amasadas de 2,1 kg de cemento y 0,966 litros de agua, de acuerdo con la Especificación API 10A/ISO 10426-1 (12), manteniendo la temperatura de ambos a $23^{\circ} \mathrm{C}$ durante el minuto inmediatamente anterior al mezclado. El cemento fue añadido durante 15 segundos a la fase acuosa a ritmo constante. El mezclado se produjo, conforme a lo establecido en el anexo $A$ de la Especificación API 10-B/ISO 10426-2 (13), a unas 14000 rpm durante 30 segundos. Para la preparación de las probetas de cemento se utilizó un molde no convencional de madera impermeabilizada con 21 perforaciones (14), con una posterior compactación mediante un pisón. La pasta fue incorporada en dos tongadas y el fraguado se realizó, durante 24 horas, a $40^{\circ} \mathrm{C}$, temperatura característica del subsuelo a 1387 pies de profundidad, antes de ser introducidas en los medios agresivos.
Pursuant to API specification 10-A/ISO 10426-1 (12), each cement batch contained $2.1 \mathrm{~kg}$ of cement and 0.966 litres of water, both maintained at a temperature of $23^{\circ} \mathrm{C}$ for one minute prior to mixing. The cement was poured into the water at a constant rate over a period of 15 seconds. Further to the provisions of Annex A to API specification 10-B/ISO 10426-2 (13), the materials were mixed at $14000 \mathrm{rpm}$ for 30 seconds. The cement specimens were made in non-conventional waterproofed wooden moulds with 21 holes (14), subsequently compacted with a rammer. The paste was poured in two lifts and allowed to set for 24 hours at $40{ }^{\circ} \mathrm{C}$, the characteristic temperature at a depth of 1387 feet, before being stored in the aggressive media. 
Puesto que las aguas de formación son ligeramente alcalinas debido a la presencia de sales de metales alcalinos y alcalinotérreos (15), se han preparado varias disoluciones a pH aproximadamente neutro, una para cada caso, enriquecidas en diversos agentes agresivos, siendo los parámetros considerados los iones magnesio, calcio, cloruro y sulfato. Las concentraciones iniciales que se han tomado, a fin de simular las aguas de formación, han sido los valores de 400, 1500 y 3000 ppm para el sulfato de sodio; 3000 y 6000 ppm para el cloruro sódico; así como 600,1500 y 3000 ppm para el cloruro de magnesio (2). El ajuste del pH se efectuó en todos lo casos con hidróxido sódico y ácido acético. Además, se utilizó agua destilada como referencia o blanco al valorar la capacidad agresiva de las disoluciones preparadas.

Se efectuaron análisis trimensuales durante más de un año a fin de determinar las concentraciones de ión calcio presentes en las disoluciones agresivas mediante un espectrofotómetro de absorción atómica modelo Perkin Elmer 2380, con el objeto de valorar la variación del citado parámetro químico en tales disoluciones en contacto con las pastas de cemento API. Además, se ha medido el $\mathrm{pH}$ de todas las disoluciones consideradas mediante a pehachímetro integral benchtop modelo IQ240. La composición mineralógica del cemento fue analizada mediante difracción de rayos $X(D R X)$, usando un difractómetro BrukerAXS D8 Advance, operando a $40 \mathrm{kV}, 30 \mathrm{~mA}$ y un incremento de paso de $0,03^{\circ}$, así como equipado con una fuente de radiación CuKa, rendija fija y detector de centelleo. Los difractogramas se obtuvieron por el método de polvo.

\section{RESULTADOS Y DISCUSIÓN}

En primer lugar, se observa que la portlandita producida por la hidratación del cemento causa un aumento del pH de las disoluciones hasta valores $12-13$ (Tablas 2, 3 y 4); aunque la presencia de iones magnesio puede suponer una ligera disminución del pH debido bien a la poca disponibilidad de la portlandita, bien a que los iones magnesio reaccionan con iones hidróxilos formando compuestos muy poco solubles como la brucita (16), con un producto de solubilidad pequeño (aproximadamente $1 \mathrm{E}-11$ ). Por otro lado, la carbonatación, consecuencia de la interacción con la atmósfera circundante, también podría influir en el leve descenso a medio plazo del pH en las distintas disoluciones. Por otra parte, el calcio aparecido en las diferentes disoluciones agresivas que han estado en contacto con las pastas de cemento procede de la portlandita, formada por la hidratación de los silicatos bicálcico y tricálcico del clínker para convertirse en tobermoritas, así como del óxido de calcio libre (17).

En el caso de interacción entre el cemento y los iones sulfato, en cantidades de hasta 200000 ppm en aguas de
Since formation water is slightly alkaline due to the presence of alkaline and alkaline-earth metals (15), the solutions were adjusted to an approximately neutral $\mathrm{pH}$ after adding the aggressive agents. The parameters considered were magnesium, calcium, chloride and sulphate ions. The initial concentrations chosen to simulate formation water were 400, 1500 and 3000 ppm for sodium sulphate; 3000 and 6000 ppm for sodium chloride; and 600, 1500 and 3000 ppm for magnesium chloride (2). The $\mathrm{pH}$ of all the solutions was adjusted with sodium hydroxide and acetic acid. The aggressiveness of the solutions was evaluated against distilled water, used as a control.

A Perkin Elmer 2380 atomic absorption spectrophotometer was used to determine the variation in calcium ion concentration in the aggressive solutions in contact with the API cement pastes. The analyses were conducted quarterly for over a year. The $\mathrm{pH}$ readings were taken with an integral benchtop IQ240 pH-meter. Powder XRD, the analytical technique used to determine the mineralogical composition of the cement, was conducted on a Bruker-AXS D8 Advance diffractometer fitted with a CuKa radiation source, fixed slit and scintillation detector. Scans were taken at $40 \mathrm{kV}$ and $30 \mathrm{~mA}$ with a step size of $0.03^{\circ}$.

\section{RESULTS AND DISCUSSION}

The first finding was that the portlandite resulting from cement hydration raised the $\mathrm{pH}$ values in the solutions to 12-13 (Tables 2, 3 and 4), despite the presence of magnesium ions, which may reduce $\mathrm{pH}$ slightly due either to the scant availability of the portlandite or to the fact that these ions react with hydroxyl ions to form compounds with a small solubility product constant, such as brucite (approximately 1E-11) (16). In the medium term, carbonation, caused by interaction with the surrounding atmosphere, may also induce a slight decline in $\mathrm{pH}$ in the solutions. Moreover, the calcium appearing in the various aggressive solutions in contact with the cement pastes had two origins: the portlandite formed when the bi-and tricalcium silicates in the clinker were hydrated and converted into tobermorites, and free calcium oxide (17).

At concentrations of up to 200000 ppm, sulphate ions can react with the portlandite in the cement to form partially 
formación, este ión puede reaccionar con la portlandita formando yeso parcialmente solubilizable que, en ausencia de iones cloruro, puede interaccionar con $\mathrm{C}_{3} \mathrm{~A}-3 \mathrm{CaO}$ $\mathrm{Al}_{2} \mathrm{O}_{3}$ - o bien con $\mathrm{C}_{4} \mathrm{AF}-4 \mathrm{CaO} \cdot \mathrm{Al}_{2} \mathrm{O}_{3} \cdot \mathrm{Fe}_{2} \mathrm{O}_{3}$ - generando, respectivamente, sulfoaluminato hidratado y etringita férrica (18). El sulfato, además, reacciona con el monosulfoaluminato cálcico hidratado $-3 \mathrm{CaO} \cdot \mathrm{Al}_{2} \mathrm{O}_{3} \cdot \mathrm{CaSO}_{4} \cdot 18 \mathrm{H}_{2} \mathrm{O}-\mathrm{y}$ la portlandita, ambos estables en el cemento, para formar etringita -3CaO$\cdot \mathrm{Al}_{2} \mathrm{O}_{3} \cdot 3 \mathrm{CaSO}_{4} \cdot 32 \mathrm{H}_{2} \mathrm{O}$ - o sal de Candlot (19). De igual modo, los sulfatos reaccionan con $\mathrm{CH}$ formando yeso - $\mathrm{CaSO}_{4} \cdot 2 \mathrm{H}_{2} \mathrm{O}$ - secundario insoluble que, a su vez, se combina con $\mathrm{C}_{3} \mathrm{~A}$ dando lugar a más etringita, compuesto cuya cristalización supone un proceso expansivo y produce fisuras en el cemento (19). soluble gypsum which, in the absence of chloride ions, may interact with $\mathrm{C}_{3} \mathrm{~A}\left(3 \mathrm{CaO} \cdot \mathrm{Al}_{2} \mathrm{O}_{3}\right.$ ) or $\mathrm{C}_{4} \mathrm{AF}$ (4CaO. $\mathrm{Al}_{2} \mathrm{O}_{3} \cdot \mathrm{Fe}_{2} \mathrm{O}_{3}$ ) to generate hydrated sulphoaluminate or ferric ettringite, respectively (18). In addition, sulphate reacts with hydrated calcium monosulphoaluminate (3CaO $\cdot \mathrm{Al}_{2} \mathrm{O}_{3} \cdot \mathrm{CaSO}_{4} \cdot 18 \mathrm{H}_{2} \mathrm{O}$ ) and portlandite, both stable phases in the cement, to form ettringite ( $3 \mathrm{CaO} \cdot \mathrm{Al}_{2} \mathrm{O}_{3}$. $\left.3 \mathrm{CaSO}_{4} \cdot 32 \mathrm{H}_{2} \mathrm{O}\right)$ (19). This ion also reacts with $\mathrm{CH}$ to form gypsum $\left(\mathrm{CaSO}_{4} \cdot 2 \mathrm{H}_{2} \mathrm{O}\right)$, an insoluble secondary product that in turn combines with $C_{3} A$ to produce ettringite, whose crystallization, an expansive process, causes the cement to crack (19).

Tabla 2 / Table 2

Concentraciones de ión calcio (ppm) y valores de $\mathrm{pH}$ en disoluciones de $\mathrm{Na}_{2} \mathrm{SO}_{4}$ y $\mathrm{NaCl}$. Calcium ion contents (ppm) and $\mathrm{pH}$ values from $\mathrm{Na}_{2} \mathrm{SO}_{4}-\mathrm{NaCl}$ solutions.

\begin{tabular}{|c|c|c|c|c|}
\hline 0 ppm NaCl & 100 d. & 200 d. & 300 d. & 400 d. \\
\hline Agua dest. / Dist. water & $230 / 12.5$ & $297 / 12.6$ & $324 / 12.7$ & $346 / 12.6$ \\
$400 \mathrm{ppm} \mathrm{Na}_{2} \mathrm{SO}_{4}$ & $281 / 12.6$ & $333 / 12.6$ & $401 / 12.7$ & $416 / 12.7$ \\
$1500 \mathrm{ppm} \mathrm{Na}_{2} \mathrm{SO}_{4}$ & $357 / 12.6$ & $379 / 12.6$ & $437 / 12.7$ & $455 / 12.6$ \\
$3000 \mathrm{ppm} \mathrm{Na}_{2} \mathrm{SO}_{4}$ & $392 / 12.7$ & $405 / 12.7$ & $451 / 12.8$ & $473 / 12.7$ \\
\hline
\end{tabular}

\begin{tabular}{|c|c|c|c|c|}
\hline $3000 \mathrm{ppm} \mathrm{NaCl}$ & 100 d. & $200 \mathrm{~d}$. & $300 \mathrm{~d}$. & $400 \mathrm{~d}$. \\
\hline $400 \mathrm{ppm} \mathrm{Na}_{2} \mathrm{SO}_{4}$ & $293 / 12.6$ & $379 / 12.7$ & $393 / 12.8$ & $401 / 12.7$ \\
$1500 \mathrm{ppm} \mathrm{Na}_{2} \mathrm{SO}_{4}$ & $369 / 12.7$ & $407 / 12.7$ & $420 / 12.8$ & $437 / 12.7$ \\
$3000 \mathrm{ppm} \mathrm{Na}_{2} \mathrm{SO}_{4}$ & $405 / 12.7$ & $419 / 12.7$ & $431 / 12.8$ & $451 / 12.8$ \\
\hline
\end{tabular}

\begin{tabular}{|c|c|c|c|c|}
\hline $6000 \mathrm{ppm} \mathrm{NaCl}$ & 100 d. & $200 \mathrm{~d}$. & $300 \mathrm{~d}$. & $400 \mathrm{~d}$. \\
\hline $400 \mathrm{ppm} \mathrm{Na}_{2} \mathrm{SO}_{4}$ & $327 / 12.6$ & $400 / 12.6$ & $416 / 12.8$ & $428 / 12.8$ \\
$1500 \mathrm{ppm} \mathrm{Na}_{2} \mathrm{SO}_{4}$ & $390 / 12.7$ & $437 / 12.7$ & $455 / 12.8$ & $465 / 12.7$ \\
$3000 \mathrm{ppm} \mathrm{Na}_{2} \mathrm{SO}_{4}$ & $415 / 12.8$ & $449 / 12.8$ & $473 / 12.9$ & $483 / 12.8$ \\
\hline
\end{tabular}

Considerando el efecto combinado existente entre los iones sulfato y cloruro, la presencia de estos últimos en el sistema atenúa en cierta medida la acción del sulfato, ya que el ión cloruro es capaz de fijarse químicamente a los aluminatos cálcicos del cemento para originar un conjunto de fases sólidas como los hidratos tipo AFm y el monocloroaluminato cálcico hidratado (20). Este último, también denominado sal de Friedel, resulta ser un compuesto menos expansivo que la etringita (21). En cuanto al calcio libre en aquellas disoluciones de $\mathrm{Na}_{2} \mathrm{SO}_{4}$ con la misma cantidad de $\mathrm{NaCl}$ (Tabla 2), la mayor concentración de $\mathrm{Na}_{2} \mathrm{SO}_{4}$ supone un incremento de la solubilidad de la portlandita (aproximadamente un 28\%) debido a las crecientes interacciones iónicas consecuencia de las mayores concentraciones de electrólitos. El aumento de la concentración de $\mathrm{NaCl}$, sin variar la cantidad de $\mathrm{Na}_{2} \mathrm{SO}_{4}$, supuso, a su vez, un incremento próximo al $15 \%$ del efecto solubilizador sobre el ión calcio.

Asimismo, dependiendo de las concentraciones de iones sulfato y cloruro en la fase acuosa, la etringita y la sal de
TIn the study of the combined effect of sulphate and chloride ions, the presence of the latter was found to attenuate sulphate action to some extent, for chloride can bond chemically to the calcium aluminates in the cement to generate a series of solid phases, such as AFm type hydrates and hydrated calcium monochloroaluminate (20). This substance, also known as Friedel's salt, is less expansive than ettringite (21). According to the free calcium content observed in $\mathrm{Na}_{2} \mathrm{SO}_{4}$ solutions containing $\mathrm{NaCl}$ (Table 2), raising the $\mathrm{Na}_{2} \mathrm{SO}_{4}$ concentration enhanced portlandite solubility (by approximately $28 \%$ ) due to the intensification of the ionic interactions resulting from the higher concentration of electrolytes. When the $\mathrm{NaCl}$ concentration was increased without varying the proportion of $\mathrm{Na}_{2} \mathrm{SO}_{4}$, in turn, calcium ion solubility climbed by nearly $15 \%$.

Moreover, depending on the sulphate and chloride ion concentrations in the aqueous phase, ettringite and 
Friedel $-3 \mathrm{CaO} \cdot \mathrm{Al}_{2} \mathrm{O}_{3} \cdot \mathrm{CaCl}_{2} \cdot 10 \mathrm{H}_{2} \mathrm{O}$ - pueden coexistir juntas, la primera puede transformarse en la segunda o viceversa (22). También se ha publicado (23) la existencia de una disolución sólida entre ambos especies, aproximándose la máxima sustitución al $50 \%$ : $3 \mathrm{CaO} \cdot \mathrm{Al}_{2} \mathrm{O}_{3}$. $0.5 \mathrm{CaCl}_{2} \cdot 0.5 \mathrm{CaSO}_{4} \cdot \mathrm{nH}_{2} \mathrm{O}$.

En lo que respecta a la acción conjunta de los iones cloruro y magnesio, y puesto que todas las disoluciones han alcanzado un $\mathrm{pH}$ igual o superior a 12, prácticamente todo el magnesio se encuentra como brucita (24), en adelante MH. La interacción del ión magnesio -en niveles de hasta algunos miles de ppm en aguas salinas- con los componentes de la pasta de cemento implica una serie de procesos que suponen la precipitación de compuestos sobre la pasta, caso de la brucita (25). La precipitación de $\mathrm{MH}$ no impide que sigan existiendo reacciones entre las disoluciones de iones cloruro y magnesio y la pasta de cemento, apareciendo el cloroaluminato de calcio decahidratado o sal de Friedel (26).

Consecuentemente, los resultados obtenidos (Tabla 3) indican la existencia de un efecto sinérgico entre los iones magnesio -principales causantes de la descalcificación del cemento- y los cloruros, pues aquel no compite con este último (16), permitiendo que el cloruro se difunda fácilmente a través de la pasta y reaccione produciendo cloroaluminato de calcio decahidratado romboédrico, polimorfo estable de la sal de Friedel a temperaturas entre 30 y $85^{\circ} \mathrm{C}(27)$, así como en concentraciones de cloruro de hasta $8 \mathrm{M}$ (20). Asimismo, la creciente presencia del $\mathrm{MgCl}_{2}$ en las disoluciones, manteniendo fija la cantidad de $\mathrm{NaCl}$, causa aumentos significativos de la concentración de calcio debido al carácter ácido del ión magnesio y al efecto salinante; igualmente, la mayor presencia de $\mathrm{NaCl}$, a concentración constante de $\mathrm{MgCl}_{2}$, también ejerce un cierto efecto salinante respecto a la solubilización del ión calcio en las disoluciones analizadas.
Friedel's salt $\left(3 \mathrm{CaO} \cdot \mathrm{Al}_{2} \mathrm{O}_{3} \cdot \mathrm{CaCl}_{2} \cdot 10 \mathrm{H}_{2} \mathrm{O}\right)$ may co-exist, with the one transmuting into the other (22). The existence of a solid solution between the two species has also been reported (23), with maximum substitution amounting to nearly $50 \%$ : $3 \mathrm{CaO} \cdot \mathrm{Al}_{2} \mathrm{O}_{3} \cdot 0.5 \mathrm{CaCl}_{2} \cdot 0.5 \mathrm{CaSO}_{4} \cdot \mathrm{nH}_{2} \mathrm{O}$.

In the solutions containing chloride and magnesium ions, since the $\mathrm{pH}$ was 12 or higher, nearly all the magnesium was in the form of brucite (24), hereafter $\mathrm{MH}$. In the interaction between magnesium ions (at levels of up to a few thousand ppm in salt water) and cement paste components, substances such as brucite precipitate on the paste (25). MH precipitation does not prevent the reaction between chloride and magnesium ion solutions and the cement paste, however, or the appearance of decahydrated calcium chloroaluminate (Friedel's salt) (26).

Consequently, the results obtained (Table 3) denoted the existence of synergies between the magnesium ions (primary cause of cement decalcification) and chlorides. Inasmuch as the two species do not compete with one another (16), the chloride could spread readily in and react with the paste to produce rhomboid decahydrated calcium chloroaluminate, a polymorph of Friedel's salt that is stable at temperatures between 30 and $85^{\circ} \mathrm{C}$ (27) and in the presence of chloride concentrations of up to 8 $M$ (20). Increasing the $\mathrm{MgCl}_{2}$ concentration in the solutions while the proportion of $\mathrm{NaCl}$ was kept constant prompted a significant rise in calcium concentration due to the acidity of the magnesium ion and its salinizing effect; higher concentrations of $\mathrm{NaCl}$ when $\mathrm{MgCl}_{2}$ remained unchanged also had a salinizing effect on calcium ion solubility in the solutions analyzed.

Tabla 3 / Table 3

Concentraciones de ión calcio (ppm) y valores de $\mathrm{pH}$ en disoluciones de $\mathrm{NaCl}$ y $\mathrm{MgCl}_{2}$. Calcium ion contents (ppm) and $\mathrm{pH}$ values from $\mathrm{NaCl}-\mathrm{MgCl}_{2}$ solutions.

\begin{tabular}{|c|c|c|c|c|}
\hline $0 \mathrm{ppm} \mathrm{NaCl}$ & $100 \mathrm{~d}$. & $200 \mathrm{~d}$. & $300 \mathrm{~d}$. & $400 \mathrm{~d}$. \\
\hline $\begin{array}{c}600 \mathrm{ppm} \mathrm{MgCl} 2 \\
1500 \mathrm{ppm} \mathrm{MgCl} \\
3000 \mathrm{ppm} \mathrm{MgCl}\end{array}$ & $\begin{array}{l}316 / 12.6 \\
467 / 12.5 \\
661 / 12.5\end{array}$ & $\begin{array}{l}345 / 12.5 \\
511 / 12.5 \\
766 / 12.5\end{array}$ & $\begin{array}{l}361 / 12.5 \\
547 / 12.5 \\
809 / 12.4\end{array}$ & $\begin{array}{l}372 / 12.5 \\
592 / 12.4 \\
838 / 12.4\end{array}$ \\
\hline 3000 ppm NaCl & $100 \mathrm{~d}$. & $200 \mathrm{~d}$. & $300 \mathrm{~d}$. & $400 \mathrm{~d}$. \\
\hline $\begin{array}{c}600 \mathrm{ppm} \mathrm{MgCl} \\
1500 \mathrm{ppm} \mathrm{MgCl} \\
3000 \mathrm{ppm} \mathrm{MgCl}\end{array}$ & $\begin{array}{l}353 / 12.5 \\
552 / 12.5 \\
750 / 12.4\end{array}$ & $\begin{array}{l}390 / 12.5 \\
648 / 12.4 \\
804 / 12.4\end{array}$ & $\begin{array}{l}424 / 12.5 \\
706 / 12.4 \\
842 / 12.3\end{array}$ & $\begin{array}{l}448 / 12.3 \\
764 / 12.3 \\
882 \text { / } 12.3\end{array}$ \\
\hline 6000 ppm NaCl & $100 \mathrm{~d}$. & $200 \mathrm{~d}$. & $300 \mathrm{~d}$. & $400 \mathrm{~d}$. \\
\hline $\begin{array}{l}600 \mathrm{ppm} \mathrm{MgCl} \\
1500 \mathrm{ppm} \mathrm{MgCl} \\
3000 \mathrm{ppm} \mathrm{MgCl}_{2}\end{array}$ & $\begin{array}{l}397 / 12.4 \\
629 / 12.4 \\
831 / 12.4\end{array}$ & $\begin{array}{l}439 \text { / } 12.3 \\
700 / 12.3 \\
899 / 12.3\end{array}$ & $\begin{array}{l}468 \text { / } 12.3 \\
752 \text { / } 12.2 \\
955 \text { / } 12.2\end{array}$ & $\begin{array}{l}491 / 12.2 \\
804 / 12.2 \\
998 / 12.2\end{array}$ \\
\hline
\end{tabular}


Al hacer referencia a las disoluciones de iones cloruro, magnesio y sulfato, la presencia del ión magnesio provoca, generalmente, una mayor acción de los iones sulfato y cloruro; ello a pesar de que la coexistencia de estos dos últimos inhibe, en parte, las acciones de cada uno de ellos sobre el cemento. El efecto del ión magnesio se debe a que éste reacciona formando $\mathrm{MH}$, provocando una mayor disolución de $\mathrm{CH}$ y, por ende, que se produzca más ettringita $\mathrm{y} / \mathrm{o}$ sal de Friedel.

En las disoluciones de $\mathrm{MgCl}_{2}$ y $\mathrm{Na}_{2} \mathrm{SO}_{4}$, asimismo, se observó la misma circunstancia que se produjo en otros casos (Tabla 4), es decir, la existencia de un incremento de la concentración del ión calcio, ya sea con el aumento de la cantidad de $\mathrm{MgCl}_{2}$, a proporción constante de $\mathrm{Na}_{2} \mathrm{SO}_{4}$, o viceversa. En definitiva, y durante todo el período objeto de estudio, los valores de las concentraciones de ión calcio resultan ser más elevadas que en casos anteriores, lo cual también se explica por las importantes interacciones iónicas existentes.
As a rule, the presence of magnesium ions intensified the effect of sulphate and chloride ions, while the co-existence of the latter two species generated mutual, albeit partial, inhibition of their respective action on cement. Magnesium ions owe their effect to the formation of $\mathrm{MH}$, which induces greater $\mathrm{CH}$ dissolution and, therefore, the production of more ettringite and/or Friedel's salt.

The findings observed for the $\mathrm{MgCl}_{2}$ and $\mathrm{Na}_{2} \mathrm{SO}_{4}$ solutions (Table 4) were the same as in the preceding cases, i.e., greater calcium ion concentration when the proportion of $\mathrm{MgCl}_{2}$ was raised while $\mathrm{Na}_{2} \mathrm{SO}_{4}$ was held constant, and vice-versa. In other words, throughout the entire period studied, it was observed that calcium ion concentration increases with magnesium ion concentration increment and, therefore, the absence of magnesium ions in the above-mentioned solutions leads to lower calcium ion concentrations, as a result of the intensity of the respective ionic interactions.

Tabla 4 / Table 4

Concentraciones de ión calcio (ppm) y valores de pH en disoluciones de $\mathrm{Na}_{2} \mathrm{SO}_{4}$ y $\mathrm{MgCl}_{2}$. Calcium ion contents (ppm) and $\mathrm{pH}$ values from $\mathrm{Na}_{2} \mathrm{SO}_{4}-\mathrm{MgCl}_{2}$ solutions.

\begin{tabular}{|c|c|c|c|c|}
\hline $600 \mathrm{ppm} \mathrm{MgCl}{ }_{2}$ & $100 \mathrm{~d}$. & $200 \mathrm{~d}$. & $300 \mathrm{~d}$. & $400 \mathrm{~d}$. \\
\hline $400 \mathrm{ppm} \mathrm{Na}_{2} \mathrm{SO}_{4}$ & $445 / 12.5$ & $473 / 12.6$ & $489 / 12.6$ & $498 / 12.6$ \\
\hline $1500 \mathrm{ppm} \mathrm{Na}_{2} \mathrm{SO}_{4}$ & 469 / 12.6 & $505 / 12.6$ & 545 / 12.6 & 569 / 12.6 \\
\hline $3000 \mathrm{ppm} \mathrm{Na}{ }_{2} \mathrm{SO}_{4}$ & $507 / 12.7$ & $561 / 12.6$ & $611 / 12.7$ & $623 / 12.6$ \\
\hline $1500 \mathrm{ppm} \mathrm{MgCl}_{2}$ & $100 \mathrm{~d}$. & $200 \mathrm{~d}$. & $300 \mathrm{~d}$. & $400 \mathrm{~d}$ \\
\hline $400 \mathrm{ppm} \mathrm{Na}_{2} \mathrm{SO}_{4}$ & $557 / 12.5$ & $599 / 12.5$ & $616 / 12.5$ & $647 / 12.5$ \\
\hline $1500 \mathrm{ppm} \mathrm{Na} \mathrm{SO}_{4}$ & $601 / 12.5$ & 637 / 12.6 & 655 / 12.6 & $674 / 12.6$ \\
\hline $3000 \mathrm{ppm} \mathrm{Na}{ }_{2} \mathrm{SO}_{4}$ & $633 / 12.6$ & $701 / 12.6$ & $743 / 12.6$ & $770 / 12.5$ \\
\hline $3000 \mathrm{ppm} \mathrm{MqCl}$ & $100 \mathrm{~d}$. & $200 \mathrm{~d}$. & $300 \mathrm{~d}$ & $400 \mathrm{~d}$ \\
\hline $400 \mathrm{ppm} \mathrm{Na}_{2} \mathrm{SO}_{4}$ & $627 / 12.4$ & $700 / 12.4$ & $716 / 12.4$ & $728 / 12.3$ \\
\hline $1500 \mathrm{ppm} \mathrm{Na}{ }_{2} \mathrm{SO}_{4}$ & $690 / 12.5$ & 737 / 12.5 & 755 / 12.5 & $785 / 12.4$ \\
\hline $3000 \mathrm{ppm} \mathrm{Na}_{2} \mathrm{SO}_{4}$ & 795 / 12.5 & 839 / 12.6 & 883 / 12.6 & 918 / 12.5 \\
\hline
\end{tabular}

Por último, y a fin de estudiar la evolución mineralógica del cemento API clase B durante la hidratación del mismo en contacto con las diferentes disoluciones preparadas, se analizaron mediante DRX las pastas de cemento conservadas en las disoluciones de $\mathrm{MgCl}_{2}, 3000$ ppm, y NaCl 6000 ppm; $\mathrm{Na}_{2} \mathrm{SO}_{4}, 3000$ ppm, y $\mathrm{NaCl}, 6000$ ppm; $\mathrm{Na}_{2} \mathrm{SO}_{4}, 3000$ ppm, y $\mathrm{MgCl}_{2}, 3000$ ppm; así como en agua destilada. En tal sentido, se obtuvieron los difractogramas de cada una de las referidas pastas a las edades de 28 días y un año. Se pudo apreciar la formación de determinadas fases estables hidratadas (tobermorita, portlandita, etringita y monocloroaluminato cálcico hidratado, entre otras) resultado de la transformación de las fases anhidras del cemento. Los análisis DRX de las pastas de cemento, sumergidas en dichos medios acuosos, también
Finally, the cement pastes stored in $3000 \mathrm{ppm} \mathrm{MgCl}$ and 6000 ppm NaCl; 3000 ppm Na $\mathrm{SO}_{4}$ and $6000 \mathrm{NaCl} ; 3000$ $\mathrm{Na}_{2} \mathrm{SO}_{4}$, and $3000 \mathrm{ppm} \mathrm{MgCl}_{2}$ solutions; and distilled water, were analyzed with XRD to study the mineralogical variations taking place in API class $B$ cement during hydration in the test solutions. Diffractograms of all the above pastes were recorded for this purpose after 28 days and one year of storage. Certain stable hydrated phases (tobermorite, portlandite, ettringite and hydrated calcium monochloroaluminate, among others) were observed to form as a result of the transformation of the anhydrous phases of the cement. The XRD analyses of the cement pastes submerged in these aqueous media also denoted the presence of calcite, brucite and, in one case, traces of thaumasite, due to the temperature (40 
indican la presencia de calcita, brucita y, en un caso, taumasita en muy poca cantidad debido a los $40^{\circ} \mathrm{C}$ de las disoluciones en contacto con la pasta de cemento (28).

El seguimiento de la composición mineralógica realizado en las pastas a las dos edades consideradas ( 28 y 365 días) permiten determinar la evolución de los principales productos de hidratación: etringita, tobermoritas, portlandita y sal de Friedel. Los resultados obtenidos (Figura 2) muestran que la portlandita es una de las fases cristalinas que aumentan en contenido con el transcurso del tiempo, tal y como indica el incremento de la intensidad de sus reflexiones; si bien la presencia del ión magnesio en disolución hace que dicho aumento sea menos significativo (Figura 2c y Figura 2d). También las tobermoritas $\left.{ }^{\circ} \mathrm{C}\right)$ of the solutions in contact with the cement paste (28).

Monitoring the mineralogical composition of 28- and 365day pastes provided insight into the variations in the main hydration products: ettringite, tobermorite, portlandite and Friedel's salt. The results obtained (Figure 2) showed that portlandite content increased with time, as indicated by the enhanced intensity of the respective reflections, although in the presence of dissolved magnesium ions the increase was less significant (Figure $2 c$ and 2d). The proportion of tobermorite also grew with the advancing hydration of the anhydrous calcium silicates,
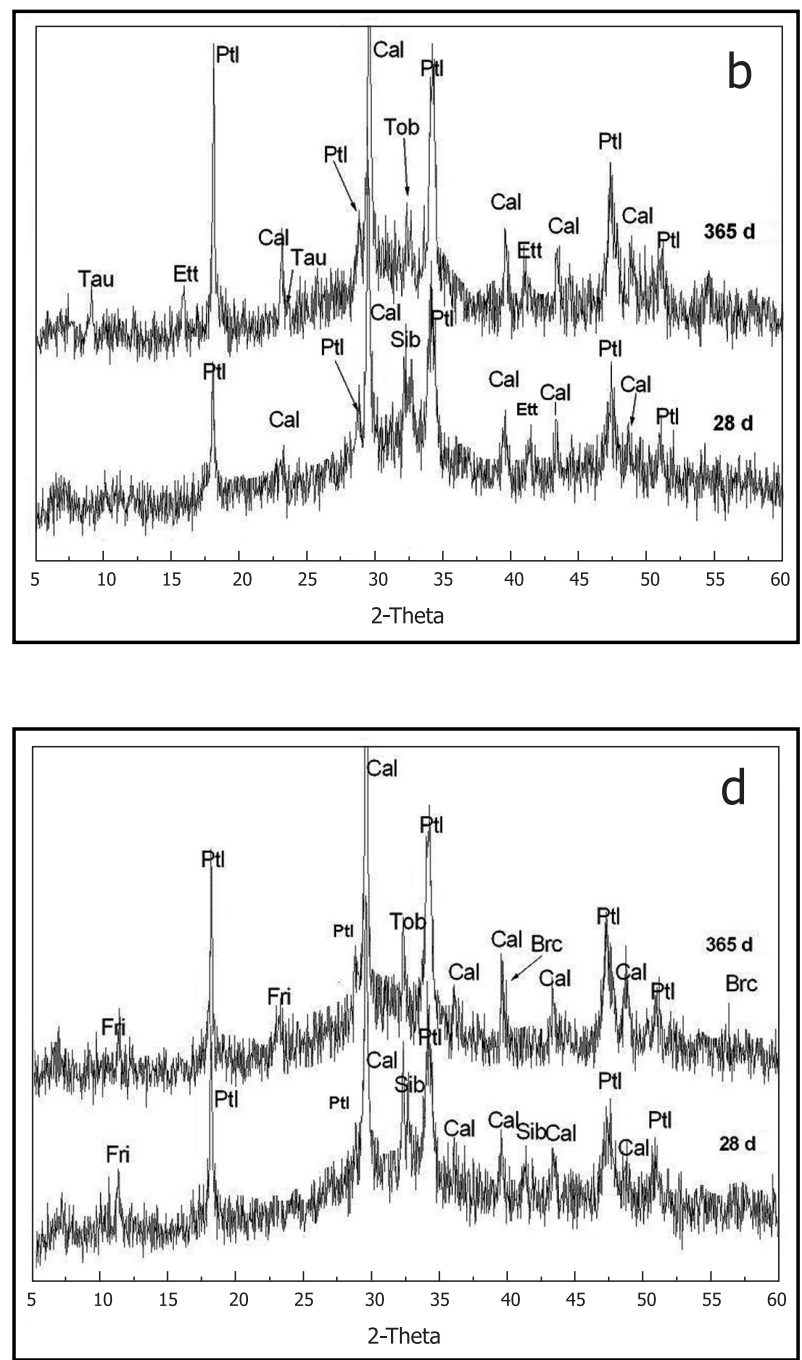

Figura 2. Mineralogía presente en el cemento API conservadas, a 28 y 365 días, en varios medios acuosos: agua destilada; b) 6000 ppm NaCl y 3000 ppm Na $2 \mathrm{SO}_{4}$; c) 3000 ppm MgCl y 3000 ppm Na $\mathrm{SO}_{4}$; d) 6000 ppm NaCl y 3000 ppm MgCl . Nota: Ptl-portlandita; Brc-brucita; Cal-calcita; Tob-tobermorita; Gyp-yeso; Sib-Silicato bicálcico; Fri-sal de Friedel; Ett-etringita; Tau-taumasita.

Figure 2. Mineralogy of API cement pastes placed in several aqueous phases at the ages of 28 and 365 days: a) MilliQ water; b) 6000 ppm NaCl and 3000 ppm Na$S_{2} \mathrm{SO}_{4} ;$ c) 6000 ppm NaCl and 3000 ppm MgCl ; d) 3000 ppm MgCl and 3000 ppm Na2 $\mathrm{SO}_{4}$. Note: Ptl-portlandite; Brc-brucite; Cal-calcite; Tob-tobermorite; Gyp-gypsum; Sib-Bicalcic silicate; Fri-Friedel's salt; Ett-ettringite; Tau-taumasite. 
son fases que se desarrollan con el tiempo al completarse la hidratación de los silicatos cálcicos anhidros; entre estos últimos se puede apreciar a 28 días la presencia de belita o silicato bicálcico, cuya velocidad de hidratación es menor.

Los difractogramas obtenidos al año indican que la sal de Friedel y la etringita también incrementan su presencia a medida que avanza el ataque, aunque son fases minoritarias en comparación con la portlandita y las tobermoritas. Cuando coexisten en el medio iones sulfato y cloruro se observa que con el tiempo predomina la fase $A_{t}$ sobre la sal de Friedel, no siendo identificada esta última en los difractogramas respectivos (Figura $2 \mathrm{~b}$ y $2 \mathrm{c}$ ).

\section{CONCLUSIONES}

Las principales conclusiones que pueden extraerse de este trabajo son, de acuerdo con la finalidad propuesta, las siguientes:

- El efecto salinante y la presencia de iones magnesio en disoluciones de los iones cloruro y/o sulfato en contacto con el cemento API utilizado potencian, significativamente, la solubilización del calcio presente en dicho material.

- Los ataques químicos de los iones sulfato y cloruro sobre la pasta se ven favorecidos por la presencia del ión magnesio en la disolución, cuya capacidad de secuestrar aniones hidróxido causa un aumento de la solubilidad de la portlandita y, como consecuencia, facilita la formación de compuestos expansivos como la etringita 0 , en menor medida la sal de Friedel .

- La comparación de los difractogramas correspondientes a las pastas inmersas en determinados medios agresivos, durante 28 y 365 días, muestra un incremento progresivo de las diferentes fases hidratadas, aunque dicho aumento está influenciado por la presencia de los distintos iones considerados y sus efectos combinados.

\section{AGRADECIMIENTOS}

Los autores desean agradecer su colaboración a la compañía Pdv S.A. one of which, belite or bicalcium silicate, was detected after 28 days in light of its slow hydration rate.

The XRD patterns obtained after one year showed that the presence of Friedel's salt and ettringite also increased as the attack advanced, although compared to portlandite and tobermorite, these were minority phases. When sulphate and chloride ions co-existed in the medium, the $A F_{t}$ phase was observed to predominate over Friedel's salt, which was not identified in the respective diffractograms (Figure $2 b$ and $2 c$ ).

\section{CONCLUSIONS}

The chief conclusions relevant to the stated purpose that can be drawn from the present study are as follows:

- The salinizing effect and presence of magnesium ions in chloride and/or sulphate solutions in contact with API class B cement significantly heightened the solubility of the calcium existing in the material.

- Sulphate and chloride ion chemical attack on the paste was favoured by the presence of magnesium ions in the solution, for their capacity to sequester hydroxide anions enhances portlandite solubility, thereby facilitating the formation of expansive compounds such as ettringite or, to a lesser extent, Friedel's salt.

- A comparison of the XRD patterns for pastes immersed in certain aggressive media for 28 and 365 days showed increases in the hydrated phases, although this growth was conditioned by the presence of the ions studied and their combined effects.

\section{ACKNOWLEDGEMENTS}

The cooperation of Venezuelan company Pdv S.A. is gratefully acknowledged.

\section{BIBLIOGRAFÍA / BIBLIOGRAPHY}

(1) Haque, M. N., Al-Khaiat, H., Kayali, O.: Strength and durability of ligthweight concrete. Cement and Concrete Composites, Vol. 26, no 4 (2003), pp. 307-314.

(2) Drever, J. I.: The geochemistry of natural waters, surface and groundwater environments, pp. 4-9. Prentice Hall. Englewood Cliffs, NJ. (1997).

(3) Martín, E.: Apuntes sobre durabilidad: el futuro del hormigón, pp. 7-8. Centro de Investigación, Desarrollo e Innovación de Materiales de Construcción. Málaga (1998). 
(4) Bryant. M.: Concrete durability. Cement and Concrete Composites, Vol. 26, no 1 (1989), pp .3-4.

(5) Economides, M. J., Watters, L. T., Dunn-Norman, S.: Petroleum well construction, p. 61. John Wiley \& Sons. Chichester (1998).

(6) Suryavanshi, A. K., Scantlebury, J. D., Lyon, S. B.: The binding of chloride ions by sulphate resistant Portland cement. Cement and Concrete Research, Vol. 25, no 3 (1995), pp. 581-592. http://dx.doi.org/10.1016/0008-8846(95)00047-G

(7) Rendell, F., Jauberthie, R.: The deterioration of mortar in sulfate environments. Construction and Building Materials, Vol. 13 , no 6 (1999), pp. 321-327. http://dx.doi.org/10.1016/S0950-0618(99)00031-8

(8) Dow, C., Glasser, F. P.: Calcium carbonate efflorescence on portland cement and building materials. Cement and Concrete Research, Vol. 33, no 1 (2003), pp. 147-154. http://dx.doi.org/10.1016/S0008-8846(02)00937-7

(9) Nelson, B. E., Guillot, D.: Well cementing, 2nd edition. Schlumberger Ed. Houston (2006).

(10) Ehtesham, S., Rasheeduzzafar, H., Al-Gahtani, A. S.: Influence of sulphates on chloride binding in cements. Cement and Concrete Research, Vol. 24, no 1 (1994), pp. 8-24. http://dx.doi.org/10.1016/0008-8846(94)90078-7

(11) Sagoe-Crentsil, K. K., Glasser, F. P.: Steele in concrete, Part I, a review of the electrochemical and thermodynamic aspects. Glusser. Mag. Concrete Research, Vol. 41, no 1 (1989), pp. 205-212.

(12) API Specification 10A, Specification for cements and materials for well cementing. American Petroleum Institute Publishing Services. Washington D.C. (2002).

(13) API Recommended Practice 10B, Recommended practice for testing well cements. American Petroleum Institute Publishing Services. Washington D.C. (2005).

(14) Barrios, J.: Preparación y estudio de un cemento PAS a partir de albero de Alcalá de Guadaira (Sevilla), pp. 97-98. Tesis Doctoral, Universidad de Sevilla. Sevilla (1975).

(15) Rodier, J. Análisis de aguas: aguas naturales, residuales, marinas; química, fisicoquímica, bacteriología y biología, p. 23. Editorial Omega. Madrid (1998).

(16) Bermejo, M. F. Resistencia química del hormigón, acción del agua desionizada, y de disoluciones de sulfatos de sodio y de magnesio sobre dos cementos Portland hidratados, pp. 172-173. Tesis Doctoral, Universidad de Sevilla. Sevilla (1988).

(17) Marchand, J., Samson, E., Maltais, Y.: Theorical analysis of the effect of weak sodium sulfate solutions on the durability of concrete. Cement and Concrete Comp., Vol. 24, no 3 (2002), pp. 317-329. http://dx.doi.org/10.1016/S0958-9465(01)00083-X

(18) Santhanam, M., Cohen, M. D., Olek, J.: Mechanism of sulfate attack, a fresh look. Cement and Concrete Research, Vol. 32 , no 6 (2002), pp. 915-921.

(19) Skalny, J., Marchand, J.: Sulphate attack on concrete revisited. Proceedings of Kurdowski. Symposium on Science of Cement and Concrete, Krakow (2001), pp. 171-188.

(20) Birnin-Yauri, U. A., Glasser, F .P.: Friedel's salt, its solutions and their role in chloride binding. Cement and Concrete Research, Vol. 28, no 12 (1998), pp. 1713-1723. http://dx.doi.org/10.1016/S0008-8846(98)00162-8

(21) Feldman, R. F., Cheng-Yi, H.: Resistance of mortars containing silica fume to attack by a solution containing chlorides. Cement and Concrete Research, Vol. 15, no 6 (1985), pp. 943-952. http://dx.doi.org/10.1016/0008-8846(85)90083-3

(22) Zhang, F., Zhou, Z., Lou, Z.: Solubility product and stability of ettringite. Seventh International Congress on the Chemistry of Cement. Paris (1980), pp. 88-93.

(23) Tady, Y., Fritz, B.: An ideal solid solution model for calculating solubility of clay minerals. Clay Minerals, vol. 16, n 3 (1981), pp. 361-373.

(24) Pourbaix, M.: Atlas of electrochemical equilibria in aqueous solutions, p. 140. National Association of Corrosion Engineers. Houston (1974).

(25) Rechendeg, W.: The effect of magnesium on concrete. ZKG International, Vol. 49, no 1 (1996), pp. 44-56.

(26) Martin del Río, J. J.: Estudio del comportamiento durable de pastas y morteros de cemento en condiciones de agresividad. Tesis Doctoral, Universidad de Sevilla. Sevilla (2004).

(27) Chatterji, S.: Mechanism of the $\mathrm{CaCl}_{2}$ attack on portland cement concrete. Cement and Concrete Research, Vol. 8, no 4 (1978), pp. 461-468. http://dx.doi.org/10.1016/0008-8846(78)90026-1

(28) Blanco, M. T., Martínez, S., Puertas, F., Palomo, A., Vázquez, T., Aguilera, J.: Formación de taumasita en morteros y hormigones, últimos avances. Cemento y Hormigón, vol. 74, no 857 (2003), pp. 18-30. 